\title{
Assessment of Educational Service Quality at Master's level in an Iranian university using based on HEdPERF Model
}

\author{
D.r Faranak Omidian ${ }^{1}$, Zahra Golchin $\mathrm{Nia}^{2}$ \\ ${ }^{1}$ Department of Education, Humanities Faculty, Dezful Branch, Islamic Azad University, \\ Dezful, Iran. \\ ${ }^{2}$ Islamic Azad University, Dezful, Iran.
}

\begin{tabular}{|c|c|}
\hline ARTICLE INFO & ABSTRACT \\
\hline $\begin{array}{l}\text { Keywords: } \\
\text { Educational Service } \\
\text { Quality, Master's } \\
\text { level, Iranian } \\
\text { university. }\end{array}$ & $\begin{array}{l}\text { The aim of this research was to examine the quality of education } \\
\text { service at master's level in Islamic Azad University of Dezful. In } \\
\text { terms of objective, this is an applied research and in regard to } \\
\text { methodology, it is a descriptive-analytical research. The statistical } \\
\text { population included all students of master's degree in Islamic Azad } \\
\text { University of Dezful. The sample size was determined using } \\
\text { stratified random sampling method in different fields of study. The } \\
\text { research questionnaire is the translated version of standardized } \\
\text { Abdullah's HEdPERF } 41 \text {-item scale [1] which is based on a } \\
\text { 5-point Likert scale. In order to determine the validity, the } \\
\text { translated questionnaire was given to the professors of educational } \\
\text { sciences. The correlation among all questions has been regarded at } \\
\text { a value of } 0.644 \text {. The results showed that the quality of educational } \\
\text { service at master's level in this university, based on chi-square } \\
\text { goodness of fit test, was equal to } 73.36 \text { and its degree of freedom } \\
\text { was } 2 \text { at a significant level of } 0.001 \text {, indicating the low desirability } \\
\text { of the services. According to Friedman test, academic } \\
\text { responsiveness has been reported to be in a higher status than other } \\
\text { dimensions with an average rank of } 3.94 \text { while accessibility, with } \\
\text { an average rank of } 2.15 \text {, has been in the lowest status from master's } \\
\text { students' viewpoint. }\end{array}$ \\
\hline
\end{tabular}

\section{Introduction}

Higher education in Iran has faced a variety of challenges in the past two decades. The increased number of universities, the large number of different educational institutions, increasing number of students and sometimes a large of number of unemployed graduates are some of the problems with which Iranian higher education deal. The quantitative development of higher education system without regard to the existing capacities, and economic, social and cultural contexts also leads to reduction in higher education system quality, especially in universities' postgraduate sector since today, a substantial number of students, due to the increasing growth of science and reduced employment, are busy studying at master's level. The number of students in postgraduate sector in Islamic Azad universities of Iran has significantly increased in comparison with the number of students in state universities since Islamic Azad universities attract students based on the policy of competitive advantage even without taking 
entrance exams in order to administer and ensure the survival of these universities. However, the quantitative growth and development of students and graduates cannot necessarily lead to a high quality. The results of many studies suggest the low quality of services in this sector. This challenge has necessitated responsibility and responsiveness in postgraduate sector of Islamic Azad universities.

Thus, service quality is the first priority for the educational planners of this sector in Islamic Azad universities and improving the quality is one of their objectives. Identifying strengths and weaknesses, recognizing opportunities and threats and trying to improve the status quo and reaching the desired status as well as attaining the highest rank are the major tasks of universities. This situation is also true of Islamic Azad University of Dezful which is one of the biggest Azad universities across the country. So the main question is that how good is quality service in postgraduate sector of Islamic Azad University of Dezful? In order to identify the dimensions of quality, the research methodology is examined.

\section{THEORETICAL BACKGROUND}

Quality is a complex and multidimensional concept the meaning of which varies from person to person. Services are behaviors which are to some extent physical and show the aspects of performance in a job. Quality is defined as a set of characteristics of a product or service which can meet the determined implicit and explicit requirements. Jafari and Osouli (2000) have given various definitions for service and product quality. Most of these definitions are customer-oriented and take customer satisfaction into account. Service quality is measured by comparing customer expectations with their perceptions. Customer expectations are what he/she expects or feels to receive from a service. And customer perceptions refer to his/her judgment on the features of a received service. In Peters' view (1999), quality exists in the observer's eyes or consumer's mind and various inferences are made about it, depending on people's mentality and attitudes, their aims and experiences. Of the most difficult practices in higher education system is evaluation. Using evaluation, one can judge to what extent educational objectives have been realized and make decisions about it. Given the concept and widespread use of "quality" in educational activities, this question can be raised that what does quality mean in educational systems? A variety of definitions have been given for quality in educational system. So, quality is of high importance in educational system. Quality in educational system is a special mode of the system and the result of a series of certain actions, which responds to a certain social needs in a specific period and place. In this quality, educational system refers to what degree the status quo can be compatible with the following situations: a) predefined standards, b) mission, objective and expectations. The role of service quality in higher education has been more addressed in the last two decades. Service quality in higher education was only limited to literature and the press. Students were regarded as the main customers of a university, who use the services provided in the university directly. This has turned into an important issue for universities and managers. Moreover, there are other service quality models some of which are mentioned here.

The SERVQUAL model is a sub branch of mental models, which also considers customers' perceptions and beliefs. This model was developed by Parasuraman et al. in the mid-1980s to measure service quality. This model tries to measure service quality in the environments where service quality is regarded as an important factor in understanding customers. EFQM Excellence model (European Foundation for Quality Management) has been introduced as the primary framework for evaluating and improving organizations. The serious design of this model began in 1989 and was introduced in 1991. It focuses on organization excellence and includes all aspects of an organization management. LibQUAL+ ${ }^{\circledR}$ has been built upon SERVQUAL, measuring and determining the service quality if libraries given the current situation and trends and by presenting tools. It has been developed in order to standardize the assessment of service quality of libraries. This model is based on the theory of approval and disapproval. This survey tool was developed in 1999. It was created based on the 
Association of Research Libraries and in cooperation with a number of researchers in the field of Library and Information Science from the University of Texas. Total Quality Management (TQM) is one of the newest theories, which has been proposed especially in 1980s and 1990s by management scholars and has been used by the most successful global organizations. This is a method for the participation of each employee and manager of an organization in matters relating to the organization. This brings a major change in the culture of the organization the objectives, ideals, ideology and the current trends of which are included. This kind of management mainly focuses on the fact that each employee and manager responds to the continuous improvement of services and products of the organization so that customers' needs are met. Recent years have seen growing interest in quality in higher education and universities and it has taken a new form and internationally, has also been the focus of interest in educational studies. HEdPERF is a model to detect and analyze the perceptions of educational centers' customers [2]. This model consists of the following dimensions 1) non-academic responsiveness; the tasks related to non-educational sector employees, 2) academic responsiveness: the rate of responses and their quality in educational sector, 3 ) reliability and trustworthiness: the ability of university to create a professional image of the field, 4) accessibility: ease of communications and using facilities and equipment, 5) programs: appropriateness, flexibility and diversity of curricula. After getting familiar with the concepts of quality, service quality and HEdPERF model, one should see whether the services Islamic Azad University of Dezful offers the students are appropriate at master's level and with regard to non-academic responsiveness, academic responsiveness, reliability and trustworthiness, accessibility and programs in the students' view and whether they are at a high level or not.

\section{LITERATURE REVIEW}

In a field research carried out in 2010 with the aim of measuring the quality of educational services concerning the master of accounting in a number of Iranian universities using the HEdPERF model, Sadeghi Arani et al. found that the quality of educational services at MA level of accounting in the universities was undesirable in all aspects. [3] evaluated the quality of educational services in Islamic Azad University of Dezful drawing upon the SERVQUAL model and concluded that the level of the students' expectations was higher than their perceptions and educational services quality was low. In the research done by Sadeghi Arani [4] using the HEdPERF model in order to assess educational services quality offered in the master of accounting in some Iranian universities, it was found that educational services quality was poor in these universities and service quality was undesirable in all dimensions (academic responsiveness, non-academic responsiveness, reliability and trustworthiness, accessibility and programs). examined the satisfaction of graduate students with service quality in Thailand universities. This study included a variety of service quality factors such as academic and nonacademic aspects, design, delivery and assessment, group size and program issues. A significant relationship was found between satisfaction and service quality variables. The results also showed that there was a difference in satisfaction level between the students who paid their own tuition fee and who have it paid by others. 


\section{MAIN OBJECTIVE OF THE RESEARCH}

To examine educational service quality at master's level in Islamic Azad University of Dezful using the HEdPERF model Dezful.

\section{METHODOLOGY}

Given the objectives, this is an applied research and in terms of methodology, it is a descriptiveanalytical research. The statistical populations consisted of all students of master's degree in Islamic Azad University of Dezful, who studied in the second half of 2012-13. The sample size was determined using stratified random sampling method between different fields of study. At first, the number of all students of different majors in postgraduate sector in the second of 2012-13 was determined. Then, given the number of students in each major in the population, a ratio of the students was selected out of the sample. The total number of the sample size was calculated using Cronbach formula. Of 160 questionnaires administered to the subjects, 154 of them were collected; the response rate was $93 \%$. The research instruments included a questionnaire. This questionnaire was a translation of standardized

TABLE I

CENTRAL AND DISPERSION INDICES WITH REGARD TO THE SCORES OF EDUCATIONAL SERVICES QUALITY AT MASTER'S LEVEL IN ISLAMIC AZAD UNIVERSITY OF DEZFUL

\begin{tabular}{|c|c|c|c|}
\hline \multirow{2}{*}{$\begin{array}{l}\text { Variables } \\
\text { Indices }\end{array}$} & \multicolumn{3}{|c|}{$\begin{array}{c}\text { Descriptive statistics } \\
\text { Students of master's degree in Islamic Azad } \\
\text { University of Dezful }\end{array}$} \\
\hline & Number & Mean & Standard deviation \\
\hline Educational services quality & 154 & 2.43 & 0.39 \\
\hline Academic responsiveness & 154 & 2.71 & 0.48 \\
\hline Non-academic responsiveness & 154 & 2.46 & 0.52 \\
\hline Reliability and trustworthiness & 154 & 2.34 & 0.46 \\
\hline Accessibility & 154 & 2.20 & 0.55 \\
\hline Programs & 154 & 2.34 & 0.52 \\
\hline
\end{tabular}

Abdullah's HEdPERF 41-item scale [1] which is based on a 5-point Likert scale, ranging from strongly disagree 
TABLE II

FREIDMAN TEST FOR COMPARING THE FACTORS OF EDUCATIONAL SERVICES QUALITY IN THE POSTGRADUATE SECTOR OF ISLAMIC AZAD UNIVERSITY OF DEZFUL IN TERMS OF DESIRABILITY

\begin{tabular}{ccccc}
\hline \hline $\begin{array}{c}\text { Coefficient value } \\
\text { (chi-square) }\end{array}$ & $\begin{array}{c}\text { Degrees of } \\
\text { freedom }\end{array}$ & $\begin{array}{c}\text { Significance } \\
\text { level }\end{array}$ & Error level & Test result \\
\hline 110.03 & 4 & 0.001 & 0.05 & $\mathrm{H}_{0}$ rejected \\
\hline \hline
\end{tabular}

with the lowest score (1) to strongly agree with the highest score (5).

In order to determine the validity of the translated version of Abdullah's questionnaire [2], it was given to the professors of educational sciences so that they could express their general opinion on the questionnaire in terms of form and content. After the changes made by them, some questions were corrected on the advice of the supervisor and advisors and in the end, 41-item educational services quality questionnaire was confirmed. The value of correlation among all of the questions has been estimated at 0.644. In the present research, Cronbach's alpha was used in order to determine the questionnaire validity the value of which was equal to $92 \%$ and since it is more than $7 \%$, the research can be regarded as desirable with a larger sample and necessary results.

\section{FINDINGS}

As can be seen in the table above, the mean and standard deviation of the scores of desirable educational services quality at master's level in Islamic Azad University of Dezful are 2.43 and 0.39 respectively. Given the obtained mean, it is below the mean of Likert scale (because the questions range from 1 to 5 the mean of which becomes equal to 3), showing that educational services quality is low at master's level in Islamic Azad University of Dezful.

The mean and standard deviation of the scores of desirable educational services quality regarding academic responsiveness at master's level in Islamic Azad University of Dezful are 2.71 and 0.48 respectively. Given the obtained mean, it is below the mean of Likert scale (because the questions range from 1 to 5 the mean of which becomes equal to 3), showing that educational services quality regarding academic responsiveness is low at master's level in Islamic Azad University of Dezful.

The mean and standard deviation of the scores of desirable educational services quality concerning non-academic responsiveness at master's level in Islamic Azad University of Dezful are 2.46 and 0.52 respectively. Given the obtained mean, it is below the mean of Likert scale (because the questions range from 1 to 5 the mean of which becomes equal to 3), showing that educational services quality concerning non-academic responsiveness is low at master's level in Islamic Azad University of Dezful. The mean and standard deviation of the scores of desirable educational services quality with regard to reliability and trustworthiness at master's level in Islamic Azad University of Dezful are 2.34 and 0.46 respectively. Given the obtained mean, it is below the mean of Likert scale (because the questions range from 1 to 5 the mean of which becomes equal to 3), showing that educational services quality with regard to reliability and trustworthiness is low at master's level in Islamic Azad University of Dezful . 
The mean and standard deviation of the scores of desirable educational services quality in regard to accessibility at master's level in Islamic Azad University of Dezful are 2.20 and 0.55 respectively. Given the obtained mean, it is below the mean of Likert scale (because the questions range from 1 to 5 the mean of which becomes equal to 3) showing that educational services quality in regard to accessibility is low at master's level in Islamic Azad University of Dezful.

The mean and standard deviation of the scores of desirable educational services quality in regard to programs at master's level in Islamic Azad University of Dezful are 2.34 and 0.52 respectively. Given the obtained mean, it is below the mean of Likert scale (because the questions range from 1 to 5 the mean of which becomes equal to 3) showing that educational services quality in regard to programs is low at master's level in Islamic Azad University of Dezful.

In order to compare the ranks of educational services quality dimensions, Friedman test has been drawn upon. The value obtained for the dimensions of educational services quality in $\chi^{2}$ is significant at a level of 0.05 given the data in the table above and with the emphasis on master's level in Islamic Azad University of Dezful, indicating a difference between the ranks of educational services quality factors in the students' view.

According to Freidman test ranking, academic responsiveness with a mean rank of 3.94 enjoys a higher status than the other dimensions and accessibility with a mean rank of 2.15 has the lowest status in master's level students of Islamic Azad University of Dezful. Academic responsiveness enjoys the most desirable status while accessibility has the lowest status.

Does educational services quality in the postgraduate sector of Islamic Azad University of Dezful enjoy a favorable status?

\section{CONCLUSION}

The results reveal that the level of educational services quality in the postgraduate sector of Islamic Azad University of Dezful is not desirable. It should be noted that most of the studies which have been conducted using this model in universities have been below normal in terms of quality. This similarity in results may show the considerable distance between the demands and expectations of Iranian students, and the present situation in educational services quality offered to the students. On the other hand, these results indicate the dissatisfaction of students with the quality of educational services in the universities as reduction in educational services quality has a direct relationship with students' satisfaction. This argument is in line with the results of similar research done in educational and noneducational environments. In fact, as studies conducted in non-educational and non-academic

TABLE III

FRIEDMAN TEST FOR RANKING EDUCATIONAL SERVICES QUALITY FACTORS IN THE POSTGRADUATE SECTOR OF ISLAMIC AZAD University OF DEZFUL

\begin{tabular}{rcc}
\hline \hline & Mean rank & Ranking \\
\hline Academic responsiveness & 3.94 & 1 \\
Non-academic responsiveness & 3.25 & 2 \\
Reliability and trustworthiness & 2.88 & 3 \\
Accessibility & 2.15 & 5 \\
Programs & 2.79 & 4 \\
\hline \hline
\end{tabular}


environments suggest that service quality has had a positive and significant effect on the satisfaction of the recipients of the services provided in those institutions. The research done in educational environments have also indicated that there is a positive and strong relationship between educational services quality and the satisfaction of students and even that of instructors. Each factor of the educational services quality suffers from some defects correction of which can enhance the quality of educational services in universities. In the present research, none of educational services quality dimensions is desirable. That is why students' dissatisfaction with educational services quality has a negative impact on their academic achievement. Some studies focusing upon educational strategies have clearly shown that the students feeling that service quality is high have had a higher level of learning and development than those who have not had felt so). Hence, it is very important that managers and providers of educational services including employees and instructors pay more attention to students' satisfaction and by evaluating and using their expectations and views respectively, provide the conditions for raising educational services quality.

\section{References}

[1] F. Abdullah, "Measuring service quality in higher education: HEdPERF versus SERVPERF," 2006. [2] F. Abdullah, "The development of HEdPERF: a new measuring instrument of service quality for higher education sector," International Journal of Consumer Studies, 30, 6, November 2006, pp569$581,2006$.

[3] F. Soltani Far, "The Examination of educational services quality in Islamic Azad University of Dezful from students' point of view using SERVQUAL," MA thesis. Islamic Azad University, Dezful branch, 2011.

[4] L. SadeghiArani, et al., "Educational services quality assessment in the postgraduate sector of accounting major from students' viewpoint in selected Iranian universities," Proceedings of the 9th Iranian accounting Conference. P.p. 217-227, 2010. 